\title{
Marta Watral*
}

\section{Czy Łemkowie mają ojczyznę poza Łemkowyną**? Literackie alternatywne modele ojczyzny w literaturze łemkowskiej}

DOI: http://dx.doi.org/1 0.12775/LC.2019.019

\begin{abstract}
Streszczenie: Po akcji „Wisła”, podczas której Łemkowie zostali wysiedleni ze swojej ojczyzny ulokowanej w południowo-wschodniej Polsce (Łemkowyna) na pólnocne i zachodnie terytoria Polski („odzyskane” od Niemiec po II wojnie światowej), pisarze łemkowscy stworzyli spójny i konsekwentny model łemkowskiej tożsamości. W tym modelu najważniejsze są język łemkowski, poczucie odpowiedzialności za przetrwanie łemkowskiego narodu i miłość do utraconej ojczyzny. Po 70 latach od wysiedleń, Łemkowyna nadal uważana jest za ojczyznę utraconą (raj utracony) i nawet ci Łemkowie, którzy nie mają już żadnego związku z tym terytorium, są zaprogramowani na odczuwanie straty. Tworzy to stan, gdy Łemkowie, którzy żyją na „nowych” ziemiach (w języku łemkowskim nadal określanych jako Чужына - obczyzna) całe swoje życie, nadal nie uważają ich za dom. Analizując łemkowskie teksty literackie wydane po akcji „Wisła”, staram się prześledzić, czy możliwe jest myślenie o Чужыıні jako o ojczyźnie i czy język łemkowski daje możliwość, by dać wyraz temu przywiązaniu i stworzyć nowy sposób kreowania tożsamości łemkowskiej poza Łemkowyną. W artykule przedstawiam dwa przykłady odmiennego do przyjętego podejścia do ojczyzny Łemków wzięte z powieści Mirosława Nahacza Niezwykłe przygody Roberta Robura oraz opowiadania Anny
\end{abstract}

\footnotetext{
* Doktorantka na Wydziale Filologicznym Uniwersytetu Jagiellońskiego, działaczka łemkowska, współpracująca przy opracowywaniu kontekstualnego słownika języka łemkowskiego.

E-mail: marta.watral@gmail.com | ORCID: 0000-0002-7949-5071.

** W artykule posługuję się nazwą „Łemkowyna” zgodnie z przyjętą w badaniach mniejszościowych zasadą używania etnonimów i nazw własnych w ich oryginalnym, etnicznym brzmieniu. Ta zasada jest od lat konsekwentnie realizowana przez badaczki i badaczy z łemkoznawczego środowiska akademickiego, do którego należę. Używam także sformułowań „Góry” i „Zachód”, które zapisuję od wielkich liter ze względu na duży ładunek emocjonalny przypisywany im w literaturze łemkowskiej. „Góry” funkcjonują jako synonim utraconej ojczyzny (Łemkowyny), są fundamentalnym symbolem tej przestrzeni, wyraźnie odróżniającym ją od nizin obczyzny. "Zachód” to terytorium, na które Łemkowie zostali wysiedleni w wyniku akcji „Wisła”. Tego określenia używa się w języku łemkowskim synonimicznie do Чужыны, a Łemków tam mieszkających nazywa się Західяками.
} 
Maślanej i Natalii Jaguś Gen Omen, a także konfrontuję je z głównym modelem zrekonstruowanym na podstawie twórczości literackiej Petra Murianki. We wnioskach wskazuję, że przytoczone przykłady są zbyt słabe, by złamać hegemonię wzorca, jednak dają nadzieję, że literatura łemkowska znajdzie sposób na przewartościowanie kategorii Ojczyzny i zaktualizowanie jej do współczesnych form łemkowskiej tożsamości.

Słowa kluczowe: Łemkowie, współczesna tożsamość łemkowska, Łemkowyna, operacja „Wisła”

\title{
Is there Lemko Homeland outside the Lemkowyna? Literary Models of Homeland in Lemko Post-Resettlement Literature
}

\begin{abstract}
After operation "Wisla" (1947), in which Lemkos were resettled from their homeland in south-eastern Poland (Lemkowyna) to the northern and western territories of Poland ("recovered" from Germany after World War II), Lemko writers created a consistent literary model of Lemko identity. In this model the most important are the Lemko language, the responsibility for the Lemko nation and the love for the lost homeland. After 70 years Lemkowyna is still considered as a lost land (lost paradise) and even those Lemkos who have no longer any connection with those territories have been programmed to feel this sense of loss. It creates a situation in which Lemkos who have lived all their lives in the "new" territories (in Lemko language those are still called Чужына - the foreign land) still are unable to consider them home.

By analyzing the Lemko literary works published after operation "Wisla", I am trying to find out if it is even possible for Lemkos to think about Чужьына as a homeland, and if Lemko language gives an opportunity to express that feeling and create a new way to build identity outside the Lemkowyna. In the paper I present two examples of different attitudes towards Lemko homeland, taken from Mirosław Nahacz's novel Niezwykte przygody Roberta Robura and Anna Maślana/Natalia Jaguś short story $Г е н \mathrm{H}$ Petro Murianka's literary work. In conclusion, I point out that the analyzed examples are too weak to break the hegemony of the model, but they also bring hope that Lemko literature will find a way to reevaluate the category of the Homeland and update it for the contemporary forms of Lemko identity.
\end{abstract}

Keywords: Lemkos, contemporary Lemko identity, Lemkowyna, operation "Wisla" 


\section{Wstęp}

0

jczyzną Łemków jest Łemkowyna ${ }^{1}$. Tytułowe pytanie nie ma na celu podania tego faktu w wątpliwość. Wynika ono z refleksji nad literackimi manifestacjami związku Łemków z ich ojczystą ziemią ulokowaną w Górach, które nie słabną, choć od 70 lat (od akcji „Wisła”) jest to ojczyzna przede wszystkim symboliczna, w niewielkim stopniu zrekonstruowana do stanu sprzed wysiedleń. W literaturze łemkowskiej próżno szukać choćby nieśmiałej deklaracji silnego emocjonalnego związku z ziemiami zachodnimi, na które Łemkowie zostali wysiedleni w 1947 roku. W języku łemkowskim te ziemie nadal są określane jako Чужыны 'obczyzna' i to słowo jest silnie zakorzenione w świadomości Łemków, nawet tych z pokolenia wnuków akcji „Wisła”, dla których Чужыьна stanowi miejsce urodzenia i to tam znajduje się ich dom rodzinny. Ze względu na znikomą aktywność pisarską młodych Łemków obrazy Łemkowyny i sposób pisania o niej zastygły w modelach i wzorcach wykreowanych przez silne łemkowskie autorytety pisarskie, wywodzące się głównie z pierwszego pokolenia po wysiedleniach, z których najważniejszym jest Petro Trochanowski (pseudonim Murianka). Choć nie doświadczył on ojczyzny sprzed wysiedleń (urodził się w 1947, już na Zachodzie), odziedziczone po rodzicach wspomnienia były tak silne, że wygenerowały najbardziej spójny i konsekwentny wzorzec łemkowskości, zapisywany przez Muriankę właściwie od początku jego drogi twórczej.

W tym artykule przedstawię alternatywne sposoby pisania o ojczyźnie Łemków. Przyjmuję, że analizowane teksty - opowiadanie Gen Omen Anny Maślanej i Natalii Jaguś (Maślana, Jaguś 2012: 146-149) oraz Część III - Na potudnie. Epilog (dalej: Epilog) z powieści Niezwykłe przygody Roberta Robura Mirosława Nahacza (2009: 419-502) przełamują obowiązujące reguły przedstawiania Łemkowyny i stanowią ważny wyłom w literaturze łemkowskiej, bo aktualizują fundamenty, na których opiera się tożsamość młodych Łemków. Zanim jednak przejdę do analizy tych tekstów, zarysuję podstawy wzorcowego modelu wytyczonego m.in. przez Muriankę, co pozwoli mi wyznaczyć miejsca wspólne i różnice w tych narracjach.

Tłumaczenia z języka łemkowskiego, o ile nie zaznaczono inaczej, pochodzą od autorki artykułu.

\section{2. Łemkowyna}

Podkreślanie związku między tożsamością łemkowską a Łemkowyną było (tuż po akcji „Wisła”) i jest nadal gwarancją trwania łemkowskiej etniczności, co przejawia się np. w twórczości literackiej powysiedleńczych pokoleń Łemków (Duć-Fajfer 2002b: 26-40). Sposoby przedstawiania ojczyzny, domu, przestrzeni bezpiecznej przez pisarzy łemkowskich prze-

\footnotetext{
1 Terytorium między rzekami Osławą i Laborcem a Popradem. O dokładnych granicach Łemkowyny pisze m.in. Duć-Fajfer 2001: 7-8.
} 
analizowała i opisała Helena Duć-Fajfer (2004: 165-178, 2012: 147-190). Badaczka zauważa m.in., że:

Odczytując figury Domu w literaturze łemkowskiej jako synekdochę Ojczyzny, stajemy na gruncie dla tożsamości etnicznej zasadniczym. Poruszamy się wszak w tych obszarach, gdzie Ojczyzna, w całej jej rozciągłości semantycznej, trwa i rozwija się głównie w przestrzeni prywatnej, w odpowiedzialności jednostkowej za wartość wspólnoty. Kształtowanie tej powinności podejmuje z dużym zaangażowaniem, z retorycznym wykorzystaniem relacji rodzinno-domowych właśnie liryka (Duć-Fajfer 2004: 169).

Konsekwencją rekonstrukcji tożsamości opartej na takim założeniu jest mityzacja i sakralizacja przestrzeni dawnej Łemkowyny. Najwyraźniej widać je w tekstach poetyckich Murianki, które wyznaczyły współczesną definicję łemkowskości i wprowadziły do niej cały ciąg symboli, skojarzeń, odniesień, paralel funkcjonujących nadal, jako spoiwa łemkowskiej grupy etnicznej. Dzięki nim, według Murianki, nawet jeśli już całkiem straciło się kontakt z łemkowską kulturą, można sobie o nim przypomnieć, odświeżyć go, zadbać o niego. Staje się to możliwe przede wszystkim dlatego, że łemkowskość w rozumieniu Murianki jest przekazywana w genach z pokolenia na pokolenie (wątek łemkowskich genów będzie istotny przy analizie tekstu Maślanej i Jaguś), stanowi element tożsamości, którego nie da się wyeliminować (można co najwyżej o nim zapomnieć albo go zaniedbać, a te procesy są odwracalne). Stąd też często pojawiające się w jego twórczości odniesienie do miłości podświadomej, cząstki w duszy każdego Łemka, która naznacza go jako odpowiedzialnego za zachowanie swojej ojczystości. Miłość do ziemi, szacunek do przodków, duma z bycia Łemkiem to podstawowe uczucia, które Murianka chce obudzić w swoim narodzie. Kształtowany przez niego wzorcowy Łemko to człowiek, który wie o tym, jak wielkim skarbem pozostaje przynależność do łemkowskiego etnosu, jest dumny z pochodzenia, kocha ojczyznę swoich przodków, czuje się odpowiedzialny za zachowanie łemkowskości. Perfekcję w tworzeniu literackich syntez mieszczących w sobie ten model ojczyzny i stosunku do niej Murianka osiągnął w Һемківскым букварі ('elementarzu łemkowskim'):

Горы Карпаты

Ту гора і там гора. За том гором - гора і за тамтом - гора. Ту близко - зелены, Аале сині. А там на краі горызонту - сивы, праві білы. То горы Карпаты. То Аемковина. (Murianka 2003: 53)

\section{Góry Karpaty}

Tu góra i tam góra. Za tą górą - góra i za tamtą - góra. Tu blisko - zielone, dalej błękitne. A tam na skraju horyzontu - siwe, prawie białe. To góry Karpaty. To Łemkowyna.

Powyższy fragment to pierwszy rzut oka na Łemkowynę. Dzięki niemu mały Łemko, który uczy się liter z tego elementarza, może rozpoznać horyzont swojego świata. Za namową Murianki patrzy na góry, ostatnie zdanie uświadamia mu, że to jest jego kraj. Od tych najbliższych zielonych gór, po te prawie niewidoczne, ginące za horyzontem. Przy okazji poznawania bukwy (litery) „h” (h jak hory - po łemkowsku 'góry') kolejne pokolenia Łemków mają nauczyć się najprostszego, bo najgłębiej zakorzenionego skojarzenia: góry to Łemkowyna, góry to moja Ojczyzna. Sześć krótkich zdań czytanki wystarcza, by wyznaczyć 
obszar bliski, rodzinny, by naznaczyć tę przestrzeń jako swoją, pokazać młodym uczniom, że gdziekolwiek teraz żyją, mają miejsce na ziemi, które jest tylko ich. Nawet jeśli to już tylko symboliczne posiadanie, nie zwalnia ich to z obowiązku poznawania i kochania tej ziemi.

Wszystkie powyższe założenia Trochanowski umieszcza już w swoim pierwszym tekście programowym opublikowanym w „Regionach” w 1987 roku - Stowo Łemka o sobie i swoim narodzie (Trochanowski 1987: 5-15). Rozpoczyna go opowieścią:

Urodziłem się w kilka tygodni po przybyciu rodziców (wraz z kolejnym transportem ludu, który sam zwał się Łemkami, a inni zwali różnie) do ziemi, określanej odzyskaną. Dziwna to była ziemia, dziwny kraj, las, pole, rzeka. Nie było tam ani duchów, ani zbójników. Nie było Icka pejsatego ani cygana Sydora - kowala. Wieczorami nigdy nie zgrał na skrzypcach Hnatko, a przecież grać umiał tak, że mrówki po ciele chodziły. Nawet dziewczęta nigdy nie śpiewały „w zelenim haju drewko rubajut”. Nie było tam nic, prócz pola, lasu, rzeki.

Ale był taki kraj, daleko, bardzo daleko, gdzie wszystko to naprawdę istniało (ibid.: 5).

Ze względu na to, że Murianka funkcjonuje w środowisku jako wzór postawy skoncentrowanej na zachowaniu łemkowskiej etniczności, tożsamości, języka, jest swoistego rodzaju eksponatem łemkowskości, niekwestionowanym autorytetem, cały czas wyznaczającym drogę do bycia dobrym Łemkiem. Dlatego jego narracje mają moc twórczą i są trudne do podważenia. Poczucie „dziwności”, o którym pisze w Stowie Łemka ... , było i jest nadal dziedziczone z pokolenia na pokolenie. Jak pisze Duć-Fajfer:

Brak, deprywacja, niedostatek, utrata, opuszczenie, rozpad, zburzenie, słabości, zagrożenie, smutek, tęsknota to określenia, którymi można by scharakteryzować kondycję Domu we współczesnej literaturze łemkowskiej. Kondycja ta wynika zarówno z realnych, historycznych faktów, jakich doświadczył Dom wysiedleńców, jak i z mniejszościowego odczucia zagrożenia asymilacją rodzimych wyznaczników odrębności przez kulturę dominującą, większościową, ich zaniku i rozpadu (2004: 179).

Mit Łemkowyny jako domu utraconego jest bardzo silnie zapisany w tym, co po akcji „Wisła” zostało z przekazu międzypokoleniowego. Nawet ci Łemkowie, którzy na Zachodzie się urodzili i tam mają swoje rodzinne domy oraz wspomnienia z dzieciństwa, czują, że ich ojczyzna jest gdzie indziej. Dobrym przykładem tego rozdarcia jest wypowiedź Seweryna Kosowskiego w reportażu To, co zostało opublikowanym w miesięczniku „Znak”:

Lubię wracać do tego, co było „przed”. Czasem sobie wyobrażam, jakby to było, gdybym żył na Łemkowynie w tamtych czasach. Moją ojczyzną jest Łemkowyna, ale to jest arkadia. Każdy człowiek ma sentyment do miejsca, gdzie się urodził, gdzie przeżył pierwsze lata życia. Ja wychowywałem się we wsi pod Legnicą i do końca życia będę miał sentyment do tego miejsca, bo tam stawiałem pierwsze kroki i poznawałem świat. [...] Jednak moja prawdziwa ojczyzna i ojczyzna mojego narodu to Łemkowyna - góry, cerkwie, kapliczki, wsie i drewniane domy. To jest naturalne, moje, a to, co jest na Dolnym Śląsku - narzucone, cudze. W górach znajduje się moja ojczyzna i wysiedlenia tego nie zmienily (Watral, Pieczek 2017: 50-51).

Kosowski jest Łemkiem wychowanym w tradycyjnej łemkowskiej rodzinie, w której akcja „Wisła” nie zerwała ciągłości przekazu międzypokoleniowego. Od dziecka słuchał od swoich dziadków i pradziadków opowieści o utraconej ojczyźnie, wychowywał się na wier- 
szach Murianki i innych tekstach przechowujących w sobie łemkowskie wartości i powysiedleńczy ból. Jego przykład pokazuje, że opisany wyżej model faktycznie działa i ma moc tożsamościotwórczą.

\section{Lemkoral}

Za najbardziej wyraźne i spektakularne wyjście poza przedstawiony w poprzednim rozdziale model opisywania ojczyzny Łemków uznaję opowiadanie Gen Omen Maślanej i Jaguś. Powstało ono jako zadanie domowe z praktycznej nauki języka łemkowskiego, zajęć prowadzonych na Uniwersytecie Pedagogicznym w Krakowie w ramach nieistniejącego już kierunku filologia rosyjska z językiem rusińsko-łemkowskim, dlatego jest ono stosunkowo krótkie i, niestety, nie doczekało się kontynuacji. Gen Omen to pierwszy tekst z gatunku sience fiction zapisany w języku łemkowskim. Już wybór gatunku stanowił przełom w literaturze Łemków i świadczył o dużej odwadze oraz determinacji autorek, bo w sytuacji, kiedy literatura dla pisarzy łemkowskich służy za narzędzie do walki o zachowanie tożsamości, trudno pokonać silną, wypracowaną przez pokolenia matrycę ideologiczną i językową, tworząc tekst całkowicie wyłamujący się ze standardowych użyć języka łemkowskiego. Podsumowanie tych użyć, a także symptomy zmęczenia smutkiem i bólem, wpisanymi w tożsamość i język Łemków można znaleźć w wydanej w 2002 roku Antologii powysiedleńczej literatury łemkowskiej (Duć-Fajfer 2002a). Paweł Korobczak w tekście O двох noезиях ( $O$ dwóch poezjach) pisze: Гніваме ся з поезийом, коли по лемківскы гварит - за дуже терпліня сотварят тым языком, а прецін гварити, то быти [Gniewamy się z poezją, kiedy mówi po łemkowsku - za dużo cierpienia przenika przez ten język, a przecież mówić znaczy być] (Korobczak 2002: 438). Jednak, jak już wspomniałam, takie głosy w literaturze łemkowskiej są sporadyczne i zbyt słabe, żeby wygenerować silny literacki bunt i przygotować miejsce na nowe formy pisania o łemkowskości.

W przypadku Maślanej i Jaguś ważne pozostaje odniesienie autorek do kultury łemkowskiej i ich z nią związek. Z tego duetu tylko Maślana jest Łemkinią, w dodatku odzyskaną, bo niewychowaną w języku i kulturze łemkowskiej (Watral, Pieczek 2017: 48-49). Języka nauczyła się dopiero na studiach, nie była zatem naturalną spadkobierczynią zapisanych w nim traum, nie miała zakodowanych w sobie modeli i ograniczeń, o których pisał Korobczak. Maślana jest także Łemkinią, która nie uczyła się łemkowskości z elementarza Murianki, nie wyrosła w micie utraconej Ojczyzny i przekonaniu bycia nie u siebie. Dzięki temu mogła użyć języka łemkowskiego w dowolny sposób i wejść w polemikę z dobrze znanym jej ze studiów łemkowskich modelem.

Akcja opowiadania Maślanej i Jaguś toczy się na kosmicznym frachtowcu, którym porucznik Sandrof wraz z dwoma innymi ekspatriantami Lolem i Teklusią uciekają przed obławą planety Lemkoral. Ta trójka to ostatni żyjący rdzenni mieszkańcy planety.

Праві тыжАен тому, узнаний през Федерацию за ребелиянта, мусіл втікати з іщы єАной облавы на Аемкоралю. Автономічна колиси плянета, по войні Імпериі з Федерацийом вошиа в УклаА ПіАбитых Територий. Тырваючы нагонкы были демонстрацийом метатехнологічной казуістыкы, а смерт і спустошыня были єй реіфікацийом. Автохтонны меш- 
канці стали ся Аля выграных одпырском субстанциі, котрій треба было затримати пульс. Пмянета быма сказана на міквіАацию (Maślana, Jaguś 2012: 146).

Prawie tydzień temu, uznany przez Federację za rebelianta, musiał uciekać z jeszcze jednej obławy na Lemkoralu. Autonomiczna niegdyś planeta, po wojnie z Federacją weszła w Układ Terenów Podbitych. Trwające nagonki byly demonstracją metatechnologicznej kazuistyki, a śmierć i spustoszenie byly jej reifikacją. Rdzenni mieszkańcy stali się dla wygranych odpryskiem substancji, której trzeba było zatrzymać puls. Planeta była skazana na likwidację.

W analizowanym tekście pojawia się bardzo niewiele informacji na temat tej planety, ich dobór zatem jest znaczący, bo pokazuje, jakie elementy łemkowskiego świata są fundamentalne dla autorki, która o swoim pochodzeniu uczyła się już jako dorosła osoba. Lemkoral (sprzed obławy dokonanej przez Federację) to spełnienie marzeń o niezależności, której Łemkowie, poza krótkim epizodem po I wojnie światowej (Magocsi), nigdy nie doświadczyli - to autonomiczna planeta, Imperium. Z dalszej części opowiadania można dowiedzieć się także, że Lemkoral miał swoje wojsko. W opisywanym momencie znajduje się jednak na granicy nieistnienia - znalazł się pod okupacją Federacji, skazany na likwidację, nie ma na nim już żadnych rdzennych mieszkańców. Lolo, Teklusia i Sandrof są ostatnimi nosicielami lemkowskiego genu. Ten gen wydaje się bardzo istotnym wątkiem w opowiadaniu i, co już zostało zaznaczone, łączy wizję Maślanej i Jaguś z modelem Murianki. Mieszkańców Lemkoralu nie definiuje wygląd zewnętrzny. Teklusia jest niską dziewczyną z dredami i tatuażem - на рамены мала татуаж - формулку в заброненым ужк গзыıу Iмnериi [na ramieniu miała tatuaż - formułkę w zabronionym już języku Imperium] (ibid.: 146), Lolo - wysokim blondynem z długimi włosami. Nie są także określeni wspólnym etnonimem. Zatem tylko gen świadczy o przynależności do narodu zamieszkującego tę planetę. Finalna część opowiadania pokazuje, że jest on także stygmatem, przepowiednią zagłady, na którą są skazani główni bohaterowie.

Przy okazji wzmianki o tatuażu Teklusi wychodzi na jaw kolejna kwestia związana $\mathrm{z}$ dramatyczną sytuacją na Lemkoralu - używanie języka Imperium jest zabronione, tatuaż to zatem manifestacja przynależności do wspólnoty i przestrzeni kulturowej, która oficjalnie nie istnieje. W dalszej części opowiadania Teklusia mówi: Техносферична Федерация думат, ито мы сме лем реліктом старого порлдку [Tесhnosferyсzna Federacja widzi nas tylko jako relikt starego porządku] (ibid.). Język łemkowski wprawdzie nigdy nie był oficjalnie zabroniony, ale przez lata uznawano go za dialekt języka ukraińskiego ${ }^{2}$, obecnie określa się go jako język zagrożony³. Nazwanie mieszkańców Lemkoralu reliktem starego porządku jest również znaczące, zbliża ich do Łemków, których najbardziej znaną identyfikacją wizualną w dalszym ciągu pozostaje czarno-białe zdjęcie starego Łemka w czusze, rozpropagowane przez Romana Reinfussa (1990). W analizowanym opowiadaniu podane są także przyczyny zagłady Imperium:

\footnotetext{
2 Prawne uznanie Łemków i ich języka nastąpiło dopiero w 2005 roku, na mocy Ustawy z dnia 6 stycznia 2005 r. o mniejszościach narodowych i etnicznych oraz o języku regionalnym. Łemkowie są w niej wymienieni jako jedna z czterech mniejszości etnicznych.

3 Był jednym z języków, które obejmowały badania w ramach grantu Endangered languages. Comprehensive models for research and revitalization, finansowanego przez NPRH (http://revitalization.al.uw.edu.pl/).
} 
Не розумієте? Они того хочут. Того нещестного імперияльного дереізму, котрий довюА до занепаду Аемкоралю. Остатні мешканці з чыстым, незаінфікуваным $\Lambda$ ЕМ-АНА, котры сами створят пустоту, означаючу брак всякой культуры, сути і почутя. Жыеме в світі, Ае правика вызначат Федерация (Maślana, Jaguś 2012: 147).

Nie rozumiecie? Oni tylko na to czekają. Na ten nieszczęsny imperialny dereizm, który doprowadził do upadku Lemkoralu. Ostatni mieszkańcy z czystym, niezainfekowanym LEM-DNA, którzy sami stworzą pustkę oznaczającą brak jakiejkolwiek kultury, istoty. Żyjemy w świecie, w którym zasady wyznacza Federacja.

Mieszkańcy Lemkoralu sami doprowadzili do swojego upadku niedostosowaniem się do zmian, które zaszły w otaczającej ich przestrzeni. Tak długo żyli w wyimaginowanym, nieaktualnym już świecie, że nie potrafili w porę i skutecznie zareagować na pojawiające się zagrożenie. To naprawdę bardzo interesująca wizja, którą można odczytać jako krytykę modelu Murianki. Maślana i Jaguś wykreowały świat, który mógłby być idealnym spełnieniem projektu rewitalizacyjnego opisanego w poprzednim rozdziale. Nosiciele LEM-DNA mają własną planetę, swój język, o który dbają i którego używają we wszystkich sferach życia, nie wstydząc się tego. Mają także wojsko, co w końcu czyni z nich autonomiczny naród z ojczyzną, której nie muszą sobie symbolicznie, za pomocą języka, dwujęzycznych tablic czy pomników z napisami w języku łemkowskim sztukować z ojczyzny kogoś innego. Jednak z jakiegoś powodu ten stan się nie utrzymuje. Podobnie jak współcześni Łemkowie, mierzą się z kryzysem, który może doprowadzić do ich całkowitej destrukcji. Mieszkańcy Lemkoralu nie przeżyli akcji „Wisła”, ale mają ekwiwalent tej traumy w postaci obławy przez Federację. LEM-DNA wydaje się tak silnie obciążone bezsilnością i słabością (które pisarze łemkowscy nadal celebrują, roztrząsając wielkie dziejowe łemkowskie traumy), że jest czymś w rodzaju dziedzicznej choroby, omenem końca.

$\mathrm{Na}$ frachtowcu, którym przemierzają kosmos, bohaterowie opowiadania znajdują współrzędne i dokładny opis planety Raj, w końcu do niej docierają. Lolo i Teklusia, ubrani w skafandry opuszczają frachtowiec, żeby zbadać planetę. Jednak jej silne promieniowanie wywołuje halucynacje. To, co Lolo i Teklusia widzą po opuszczeniu frachtowca, bardzo przypomina krajobraz Łemkowyny: Теклюся стояла як загіпнотызувана. Перед єй очами розтігали ся пасма зелени і тіни. Блищзачы в сонци рікы, зароснены лісом горбы [Tеklusia stała jak zahipnotyzowana. Przed jej oczami rozciągały się pasma zieleni i cienia. Rzeki błyskające w słońcu, pagórki porośnięte lasem] (Maślana, Jaguś 2012: 149). Ekstaza, w którą wpadają, doprowadza ich do samobójstwa. Tym samym w całym wszechświecie zostaje ostatni nosiciel LEM-DNA - porucznik Sandorf.

Opowiadanie kończy się zdaniem Чac наглиm [Czas nagli] (ibid.). Uratowanie Lemkoralu staje się coraz mniej prawdopodobne. 


\section{Południe}

Mirosław Nahacz był Łemkiem. Wychował się na Łemkowynie, języka nauczył się w domu, czuł bardzo silny związek z przestrzenią i kulturą łemkowską (Nęcka 2014: 227-241) ${ }^{4}$. W opowiadaniu Ojciec narrator przedstawia się jako wzorowy odbiorca przywoływanej czytanki z elementarza Murianki, idealny adept łemkowskości:

Wtedy cały świat zamknięty był w przestrzeni dostrzegalnej z dachu mojego domu, na który zabierał mnie ojciec, kiedy zimny wiatr strącał antenę telewizyjną.

Pamiętam obraz - nieskończenie, które wpasowane jest w pewną formę, setki miejsc ograniczonych czymś, co zatrzymuje wzrok. On nigdy nie zdążał rozpłynąć się w swoim ograniczeniu, w niemocy dostrzeżenia czegoś, co znajduje się zbyt daleko, bo zalesione góry, które zdecydowanie kończyły ten świat, były zbyt wyraźne. Zawsze byłem przekonany, że poza moją wioską nic nie istnieje, że ci ludzie, którzy pojawiają się znienacka, muszą pochodzić z tych miejsc, które widać jedynie z dachu mojego domu, a do których nigdy nie mogłem tak naprawdę dotrzeć. Ta przestrzeń, wokół której horyzont [kreślił zarysy] pofalowanego okręgu, nie była płaska, co utwierdzało mnie w przekonaniu, że idąc odpowiednio długo w jednym kierunku, wyjdę w końcu z zupełnie [innej] strony (Nahacz 2012: 145).

W każdej powieści Nahacza pojawia się odniesienie do Łemkowyny. Najbardziej znaczące i wyraźne są te w Opowieści starucha z Bociana i Loli (Nahacz 2005) oraz przywoływanym tu Epilogu. Jednak jest to pisarz sporadycznie analizowany w kontekście łemkowskim (Misiak 2012: 95-104). Pisze się o nim raczej jak o polskim pisarzu łemkowskiego pochodzenia i nie umieszcza w analizach literatury łemkowskiej. Do tej pory jego teksty nie wchodziły też do kanonu lektur z języka łemkowskiego ${ }^{5}$. Pod tym względem jest, podobnie jak Maślana i Jaguś, pisarzem z zewnątrz.

W Epilogu powieści Niezwykłe przygody Roberta Robura Południe odgrywa kluczową rolę dla rozwoju fabuły. Robert Robur ucieka tam ze swoją dziewczyną Mają ze Świetlnego Miasta, w którym czuje, że każdy jego ruch jest z góry zaplanowany i obserwowany. Miasto w ujęciu Nahacza to dokładne przeciwieństwo Południa (rodzinnych stron Robura) - nigdy i nigdzie nie doświadcza się tam ciemności (bo ciemność pozwala ludziom na intymność, daje im wolność, na którą władze miasta nie chcą pozwolić), mieszkańcy poddawani są ciągłej inwigilacji, rytm ich życia wyznacza emitowany codziennie serial W'śiekłość i wrzask. W opisie miejsca akcji Epilogu nie pada słowo Łemkowyna, określane jest ono Południem, końcem świata, to miejsce, w którym stoją drewniane domy, a lokalsi piją eter, co pozwala je porównać do wsi łemkowskich.

Podróż Robura na Południe trwa bardzo długo. Po opuszczeniu Zony (strefy wpływów Świetlnego Miasta) krajobraz zaczyna się zmieniać, pojawiają się lasy i, przede wszystkim, ciemność. Zmienia się także sposób przedstawiania czasu, akcja zwalnia, droga trwa parę dni, choć Robur i Maja ciągle jadą. Moment przejścia między strefami jest bardzo wyraźnie zaznaczony. Południe rozmywa zasady, które porządkowały czas i przestrzeń z poprzednich części powieści, dziejących się w Mieście:

${ }^{4}$ Tam też pełna bibliografia tekstów krytycznych o powieściach Nahacza.

5 W nowej podstawie programowej, przygotowywanej w związku z reformą edukacji, do listy lektur dla liceów, techników i szkół branżowych została wpisana i przetłumaczona na język łemkowski powieść Bombel. 
Potem zaczął się las i wjechali w świat, który pozwolił zapomnieć im o mieście, zupełnie jakby przestrzeń, w której się znaleźli, miała wewnętrzną zdolność wymazywania przeszłości lub oddalania jej tak daleko od chwili obecnej, że ludzka pamięć nie nadawała się już do wspominania. Miasto wydarzyło się dawno temu, przed opowieścią (Nahacz 2009: 432).

Robur ma w sobie zakodowaną drogę, podświadomie wie, gdzie ma jechać.

Robur powoli przypominał sobie tę przestrzeń, czy raczej to ona przypominała się jemu. Miejsca zaczynały pasować, jak utracone, zagubione fragmenty układanki, która tkwiła w jego głowie. Strumyki, smak idealnie czystej źródlanej wody, przefiltrowanej przez kilometry podziemi i tony piasku - było kilka takich, ważniejszych niż inne, wspomnień (ibid.: 436).

Południe nie jest jednak sielskim krajobrazem skonstruowanym ze wspomnień dzieciństwa Robura. Gdy dojeżdżają do zamieszkanych terenów, okazuje się, że, podobnie jak Lemkoral w opowiadaniu Maślanej i Jaguś, Południe znajduje się w sytuacji zagrożenia, oblawy, w stanie rozpadu, destrukcji:

Dziewiątego dnia wieczorem dojechali do pierwszej wioski. Wśród kilkunastu domów tylko kilka było z cegieł, resztę wybudowano z drewna. Kiedy zorientowali się, że wieś pełna jest ludzi w mundurach, chcieli zawrócić, ale było za późno, na drodze nagle pojawił się szlaban, obok szlabanu stała chatka, obok chatki dwóch chudych typów i każdy z nich miał karabin zawieszony na pasku i niską rangę na pagonach. [... ] Jeden z nich powiedział: - Jest już za późno. Ewakuacja trwa (ibid.).

W Epilogu zawarto jedno z najwyraźniejszych literackich odniesień do akcji „Wisła”, zapisanych w języku polskim - i to w powieści wydanej przez duże polskie wydawnictwo. Nahacz wykorzystuje obrazy, które miał zapisane w świadomości przez swoich rodziców i dziadków, odtwarza przekazaną przez nich narrację o wysiedleniach. Ten wątek pojawia się często w jego powieściach. Bombel, miejscowy pijaczek, będący narratorem powieści o tym samym tytule, opowiada:

Bo są też tacy, którzy obecnie mieszkają w pierwszym domu murowanym, jaki wybudowano w mojej wsi zaraz po wojnie w czterdziestym siódmym, i ten facet $\mathrm{z}$ rodziną, właściciele tego domu, długo w nim nie pomieszkali, bo niedługo po tym, jak się wprowadzili, już musieli stamtąd spierdalać, i mieli tylko godzinę na spakowanie, a wszystkiego pilnowali żołnierze (Nahacz 2004: 86).

Nahacz przedstawia Południe jako przestrzeń straconą, obciążoną traumą, która konstytuuje jej istnienie i jednocześnie zaświadcza o jej faktycznym nieistnieniu.

Oni obiecywali im zawsze to samo: „Miasto przyjdzie do was, nie musicie się martwić, musicie czekać”. Ludzie cierpliwie czekali, a teraz okazało się, że ktoś ich okłamał. Pojawiły się tory. Przyjechały bydlęce wagony. Ktoś wtedy zauważył: „To dla nas”. Potem pojawili się ludzie w mundurach. Minimalizacja zaludnienia poza miastem. Tylko miasto nadaje się do mieszkania. Tutaj nie da się mieszkać. Dziczejecie. Jesteście jak zwierzęta. Potrzebujecie światła. Czekają na was piękne mieszkania. Dla każdej rodziny. Mieszkania w prawdziwym świecie. W mieście pełnym światła (ibid.: 437-438). 
Podobnie jak w opowiadaniu Gen Omen, mieszkańcy Południa zostają napadnięci przez lepszą, bardziej rozwiniętą cywilizację, jako relikty starego porządku, które nie są dostosowane do prawdziwego życia. Władze Świetlnego Miasta zarządzają ewakuację ludności, teoretycznie po to, by im pomóc wyjść ze zdziczenia, faktycznie - dlatego że boją się ich ciemności, nie rozumieją przestrzeni, w której mieszkają, widzą w niej ogromne zagrożenie:

Kryzys był oszołomiony czystością tego, co wdychał, tym, co działo się z powietrzem, chmurami i lasem. Przyroda wyglądała jak po wizycie w gabinecie biologicznej odnowy, ziemia rozbudziła się tak gwałtownie, jakby przez cały dzień nie padał na nią deszcz, tylko amfetamina. Grzyby przebijały się przez glebę, wszystko pięło się w górę, do słońca, chlorofil niemal skapywał z liści, ruszyła potężna maszyna i Mirosław Kryzys dawno już nie czuł się tak bardzo nikim, jak malutka dioda na tle słońca, zdychający świetlik, który usiadł nie na tej latarni co trzeba (ibid.: 458).

Robur ucieka na Południe, żeby znaleźć odpowiedzi. Tam wszystko się zaczęło (co pokazuje zakończenie powieści), tam też wszystko się kończy. Południe spaja klamrą życie Robura. Gdy trafia do swojej wsi, rozmawia ze starcem po łemkowsku (w powieści rozmowę zapisano łacinką, ale nie ma wątpliwości, że bohaterowie posługują się językiem Łemków). Ten język jest tajnym kodem, który umożliwia wyrwanie się spod władzy Miasta. Nahacz $\mathrm{w}$ powieści planowanej jako najważniejsza w dotychczasowej karierze ${ }^{6}$ wprowadził jako alternatywną przestrzeń bardzo dobrze sobie znane miejsce, zaktualizowane jednak o obawy człowieka, który musi połączyć w sobie dwa tak różne światy - Południa i Świetlnego Miasta - oraz znaleźć nową jakość, która pozwoli mu przetrwać.

Robur oddychał bez najmniejszego problemu, nic nie zalepiało jego płuc. Tlen miał w sobie słodki podkład gnijącej ściółki, ostry zapach bezwstydników i bielunia i był jak coś, czego zawsze mu brakowało. Robur czul, jak tutejsze powietrze uzupełnia w nim brakujące miejsca, o których zawsze myślał, że pozostaną puste (ibid.: 433).

\section{Wnioski}

Paradygmat pisania o ojczyźnie Łemków jest ustalony, konsekwentnie przez pisarzy łemkowskich realizowany i dokładnie opisany (przede wszystkim w cytowanych pracach DućFajfer). Literacki obraz Łemkowyny odtwarza to, co udało się zachować i zrekonstruować ze wspomnień i wrażeń sprzed wysiedleń, dzięki temu nadaje się do odbudowania albo przynajmniej zaznaczenia dawnego przekazu międzypokoleniowego. To bez wątpienia bardzo istotne i na takim myśleniu wychowuje się młode pokolenia Łemków, a także studentów wspomnianej filologii łemkowskiej, bo bez silnego poczucia przynależności i związku z korzeniami, źródłem kultury, języka, wierzeń, nie można budować swojej tożsamości. Jednak współcześnie ten model przestaje się sprawdzać, szczególnie w przypadku Łemków, których tożsamość etniczna nie ma już tak silnych odniesień do mitycznej, straconej ojczy-

${ }^{6}$ Nie dokończył jej jednak, popełnił samobójstwo zanim wprowadził wszystkie planowane poprawki i dopisał zakończenie. 
zny. Język łemkowski i literatura łemkowska wytworzyły sprawnie działające mechanizmy obronne swojej integralności, które z jednej strony są ważne i słuszne, bo zachowują fundament do rewitalizacji ( $w$ ostatnich latach dziejącej się bardzo intensywnie, szczególnie przez rozwój studiów łemkoznawczych w Polsce), z drugiej jednak blokują literacką ekspresję tożsamości niepewnych, dla których gen łemkowski wcale nie wywołuje tęsknoty za Górami, bo ich ojczyzna jest ulokowana gdzie indziej. To, że Чужыны nigdy nie została nazwana przez Łemków Nową Łemkowyną, czyli nie nastąpił moment symbolicznej akceptacji terytorium, na którym kolejne pokolenia Łemków żyją już od 70 lat, w moim odczuciu działa na niekorzyść dla tożsamości i literatury przez nią generowanej. $\mathrm{Z}$ tych względów przywołane teksty uznaję za istotne i ważne zjawisko w literaturze łemkowskiej.

Maślana i Jaguś, by przełamać ten impas, musiały przenieść gen łemkowski w kosmos i tam zbudować całkowicie alternatywny świat. Lemkoral jednak jest na granicy istnienia, został jeden natywny mieszkaniec planety, czas nagli, a rozwiązań na zachowanie i odbudowanie Imperium nie ma.

Nahacz opisuje Południe na podstawie symboli i odniesień wyniesionych z łemkowskiego domu, nie jest to jednak wizja spokojnej arkadii, sielskiego kraju dzieciństwa, jaką można znaleźć u Murianki. Pisarz przeprowadza na Południu kolejną akcję „Wisła”, ewakuuje mieszkańców do Miasta Światła, pokazuje, że ta ziemia jest już stracona, naznaczona traumą, która cały czas się odtwarza. Mieszkańcy Południa są ciągle bardzo mocno zakorzenieni w kulturze (zachowali wierzenia i kulty, np. wierzą w niszczącą moc mamuna), przestrzeni i języku, niedługo jednak będą musieli opuścić swoją ojczyznę. Jest już za późno na ratunek. Ewakuacja trwa. Południe powoli przestaje istnieć.

Okazuje się zatem, że opisanie ojczyzny Łemków inaczej niż przez pełne tęsknoty idealizujące obrazy uruchamia skrajne względem nich wizje katastroficzne. Wydaje się, że Łemkowie nie bardzo wiedzą, jak mieliby wymyślić i zapisać własną ojczyznę, w sytuacji gdy jej utrata w wyniku akcji „Wisła” nadal pozostaje traumą fundującą ich współczesną tożsamość. Kto wie, może niedługo ktoś napisze po łemkowsku afirmatywną opowieść o tym, że kocha swój dom na Zachodzie i nie oddałby go za żadne skarby świata, bo jak jest w Górach, to czuje się źle z tym krajobrazem i nie jest w stanie jeździć po tych krętych ścieżkach bez uaktywnienia się choroby lokomocyjnej. Pytanie tylko, czy wtedy Łemkowie uznają go za jednego ze swoich.

\section{Zapis oryginalny publikacji w języku lemkowskim}

Коробчак, Павем 2002. „О Авох поезиях”.

Масляна, Анна, Талька Ягусь 2012. „Ген Омен”.

Мурянка, Петро 2003. А я знам азбуку. Иемківскій буквар.

Трохановскій, Петро 1995. Мамко, куп мі книжку. Антольотія діточой поезиі. Новий Санч: Стоваришыня Аемків. 


\section{Bibliografia}

Duć-Fajfer, Helena 2001. Literatura łemkowska w drugiej połowie XIX i na poczatku XX wieku. Kraków: Polska Akademia Umiejętności.

— (red.) 2002a. Czy to tęsknota, czy nadzieja. Antologia powysiedleńczej literatury temkowskiej. Legnica: Stowarzyszenie Łemków.

2002b. „Powysiedleńcza literatura łemkowska w Polsce jako etos trwania”. W: Duć-Fajfer 2002. 26-40.

2004. „Etosowy i konstruujący model współczesnej liryki łemkowskiej”. Przegląd Polonijny 3: $165-178$.

2012. Pomiędzy bukwa a litera: współczesna literatura mniejszości białoruskiej, ukraińskiej i łemkowskiej w Polsce. Kraków: Wydawnictwo Uniwersytetu Jagiellońskiego.

Korobczak, Pawel 2002. „O dwoch poezyjach [O dwóch poezjach]”. W: Duć-Fajfer 2002. 438.

Magocsi, Paul R. The Ukrainian question between Poland and Czechoslovakia: the Lemko Rusyn Republic (1918-1920). Publikacja on-line dostępna na stronie: http://www.carpatho-rusyn.org/lemkos/lemrepub.html [29.10.2017].

Maślana, Anna, Natalia Jaguś 2012. „Gen Omen [Gen Omen]”. W: Helena Duć-Fajfer (red.). Rocznik Ruskiej Bursy 2012: 146-149.

Misiak, Małgorzata 2012. „Oblicza Łemkowszczyzny - o literackiej kreacji miejsca”. W: Helena DućFajfer (red.). Rocznik Ruskiej Bursy 2012: 95-104.

Murianka, Petro 2003. A ja znam azbuku. Łemkiwskij bukwar [A ja znam alfabet. Łemkowski elementarz]. Warszawa-Legnica: Fundacja Wspierania Mniejszości Łemkowskiej „Rutenika”.

Nahacz, Mirosław 2004. Bombel. Wołowiec: Wydawnictwo Czarne.

2005. Bocian i Lola. Wołowiec: Wydawnictwo Czarne.

-2009. Niezwykłe przygody Roberta Robura. Warszawa: Wydawnictwo Prószyński i S-ka.

2012. „Ojciec”. Tekstualia 4 (31): 145.

Nęcka, Agnieszka 2014. „W pogoni za uciekającą opowieścią. O prozie Mirosława Nahacza”. W: Agnieszka Nęcka, Dariusz Nowacki i Jolanta Pasterska (red.). Skład osobowy. Szkice o prozaikach wspótczesnych. Katowice: Wydawnictwo Uniwersytetu Śląskiego. 227-241.

Reinfuss, Roman 1990. Śladami Łemków. Łódź: Wydawnictwo PTTK „Kraj”.

Trochanowski, Piotr 1987. „Słowo Łemka o sobie i swoim narodzie”. Regiony 2-4: 5-15.

Trochanowskij, Petro 1995. Mamko, kup mi knyżku. Antologija dimoczoj poezyj [Mamo, kup mi książkę. Antologia poezji dziecięcej]. Nowyj Sancz: Stowariszynia Łemkiw.

Watral, Marta, Urszula Pieczek 2017. „To, co zostało”. Znak 746-747: 47-53. 